\title{
Coordination of higher educational institutions and professional library associations - the key to training quality rise of librarians of XXI century
}

\author{
Natalia I. Gendina \\ doctor of pedagogical sciences, professor \\ director of R\&D Institute of Information Technologies \\ of Social Sphere of Kemerovo State University \\ of Culture and Arts, Russia
}

Introduced by IFLA the slogan: "Libraries are the heart of information society" essentially changes the approach to the librarians training. The transition from information society to knowledge society, transformation to modern education paradigm made necessary cooperation of higher educational institutions and professional library associations. The main forms of this cooperation are discussed.

"Libraries are the heart of information society". Presented by IFLA, the slogan "Libraries are the heart of information society" exactly reflects the key role that libraries have to play in solution of one of strategic tasks of modern society: in providing access to information and knowledge for all. The 69th IFLA Council meeting (Berlin, 2003) passed the following resolution on the World Summit on the Information Society: "Whereas the world Summit for the Information Society offers a unique opportunity to be recognized as the heart of the information society... it is resolved that IFLA calls upon all governments to address the growing gap between the information rich and the information poor, and promote library development programs for poor rural and urban populations, library instruction through libraries, and the strengthening of library educational programs".

According to this resolution Russian Library Association (RLA) held in 2004 the $9^{\text {th }}$ Annual Session and Conference under the slogan: "Libraries are the heart of information society". At this largest forum of Russian library professionals among the most important ones the problem of library staff training called to provide Russia's entering into information society was discussed. At that practicing librarians and higher educational institutions' teachers were united in admission that it is necessary to change essentially the organization of library-information 
specialists' training. So, if we really believe that "Libraries are the heart of information society", then the problem of quality of librarians' training gains a special meaning. However, it is impossible to answer the question of what exact changes must be done in this training without taking into consideration the context of these changes which, firstly, are connected with information society development, and, secondly, with the transformation of modern education paradigm.

\section{From information society to knowledge societies}

It is known that one of the main theses of UNESCO to World Summit for the Information Society is in that for overcoming the digital inequality it is needed to move along the way of knowledge societies' building. In his interview UNESCO's Assistant Director-General for Communication and Information Abdul Waheed Khan explained how the concept of "knowledge societies" differs from that of the "information society" and why, in a world where $80 \%$ people still lack access to basic telecommunications, knowledge societies are the key to a better tomorrow. He said: "Actually, the two concepts are complementary. Information society is the building block for knowledge societies. Whereas I see the concept of "information society" as linked to the idea of "technological innovation", the concept of "knowledge societies" includes a dimension of social, cultural, economical, political and institutional transformation, and a more pluralistic and developmental perspective. In my view, the concept of "knowledge societies is preferable to that of the "information society" because it better captures the complexity and dynamism of the changes taking place"[1]. Answering the question: "what is the role of education in this process?" he underlined that "education - both in traditional and in new settings - is the key to creating equitable knowledge societies".

Having based on the analysis of special publications, it is possible to state the main factors characterizing information society and knowledge societies:

- information and knowledge is the main transforming force of the society, and information resources are the strategic resources of society;

- global informatization, rapid development of information - communication technologies are the base of a new economics, economics of knowledge;

- novelty, fleetingness, acceleration are the most characteristic features of life;

- innovation cycle of both industrial and social technologies amounts to 6-8 years, outstripping generations' changing;

- life-long education and ability to re-qualify are part and parcel of preservation of a person's social status;

- every person's destiny depends on the ability to find timely, obtain, apprehend adequately and use productively new information.

These factors, on my deep conviction, must be taken into consideration at any 
specialists' training, but they have special meaning in perfection of library-information staff training.

\section{Transformation of modern education paradigm}

It should be underlined that library education development cannot be done without taking into consideration the situation existing in the world system of education. Universally recognized that it overcomes the crisis. This crisis of the education system is alongside with such global crises as ecological, raw-material, energetical ones etc. Here are the most important contradictions specific for the crisis of education system:

- between education's orientation to the transfer as more as possible produced knowledge to learners and their physical inability to acquire the "avalanche" of knowledge;

- between traditional "supporting" education accounted to relative stability of society and gradual development of social processes and more dynamic and complex developing society;

- between swift development of information-communication technologies and the inertness of instructional technologies;

- between cultural-national specific character of education systems and the need of modern society in unified standards and criteria of education quality.

The reaction to these contradictions became the appearance of a new education paradigm - education paradigm for tomorrow. Its specific features are:

- mastery of work skills with any information, with heterogeneous, contradicting data, skills' formation of independent (critical) and not reproductive thinking;

- shift of the main accent from assimilation of large amounts of information accumulated for future use into assimilation of ways of long-life acquiring new knowledge and ability to learn independently.

\section{Key competencies}

The new education paradigm presupposes the transition from the traditional principle "to form professional knowledge, abilities and skills" to the principle "to form professional competence".

Competence is a sphere of relations existing among knowledge, abilities and actions in human practice. The connection is evident: without knowledge, abilities and skills there is no competence, but not all knowledge, abilities and skills and not every situation can be considered to be competences. I should remind that 
the idea of key competences was introduced by experts of European Council in education. They identified five groups of key competences which have a special meaning and which must be acquired by citizens of information society:

1. Political and social competences, such as an ability to take responsibility, participate in mutual take decisions, regulate conflicts by an unviolent way, participate in functioning and improving of democratic institutions.

2. Competences concerning life in multicultural society. In order to prevent racialism or xenophobia, spreading the climate of intolerance education must "equip" the youth with cross-cultural communications, such as recognition the differences, mutual respect to each other, ability to live in peace with people of other cultures, languages, and religions.

3. Competences connected with abilities of oral and written communication, which are so important in work and social life that persons who do not have such competences can be excluded from the society. To have a good command of foreign languages taking ever-growing importance belongs to this group of communication.

4. Competences connected with the rise of information society. A good command of new technologies, understanding of their use, advantages and disadvantages, ability of criticism to information spreading by mass media and advertisement.

5. Ability to long-life study as the base of continuing training in professional, private and social life.

Thus, the solution of the problem of training quality rise of librarians must be fulfilled with taking into account the three factors characterizing modern education system in general:

- information society development and its transformation into knowledge society;

- change of "education for the rest of life" paradigm into "education for long-life" paradigm;

- transition from the traditional principle "to form professional knowledge, abilities and skills" into the principle "to form professional competence".

\section{Cooperation of higher educational institutions and professional library associations}

Alongside with general systematical factors and demand claimed to modern education the important factor of optimization of modern library-information education is the cooperation of educational institutions and professional library associations. It is the professional library community that can and must formulate the require- 
ments both to the contents of professional education and to the quality of libraryinformation specialists' training.

For many countries having long traditions of professional library associations which fulfill the functions of results' evaluation of educational institutions' activity in librarians' training this problem may have been solved. However, for modern Russia this problem is rather actual. Its actuality is conditioned by the fact that even in the recent period, the period of the USSR, under conditions of totalitarizm, the activity of educational institutions was extremely ideological, strictly controlled on the part of the state, and professional library association didn't exist at all.

\section{Russian Library Association (RLA) as a public professional organization was} established only in 1994. RLA's establishing was called up by the necessity to activate public library movement, to unite forces and coordinate the actions not only communities and organizations, but working staff of libraries of all levels, types and specializations, education and other institutions in order to preserve and develop librarianship in Russia. Nowadays, RLA is an important corporate professional organ within the structure of which there are 31 sections and 3 round table conferences. Among all the sections I'd like to mark up the section of library profession, librarians and long-life education and the section of R\&D in library-information activities which are closely connected with the tasks' salvation of quality perfection in library specialists' training.

I'm a member of both sections and the head of the R\&D section. At the same time, first of all, I'm a teacher, professor of the University which trains libraryinformation specialists. So, my most important task is to provide a productive dialogue between educational institutions and RLA which reflects demands of professional community to the level of undergraduates' training.

\section{The problem of elaborating the mechanism of cooperation of higher educational institutions and library associations}

The main problem is to elaborate an effective mechanism of cooperation of higher educational institutions and library associations. It gets a special actuality under conditions of development and introduction of state educational standards. The standards are considered to be the most important tools of quality evaluation of library education and staff training.

The activity in education standardization in general and library education as a part got development in Russia not long ago, namely from the middle of the 90s. Standardization development is mainly connected with the education contents' renovation. The main pre-conditions for its renovation are: principal changes of Russian social-economical fundamentals: fleeting development of new information 
technologies, global informatization and information society establishing; the change of factors influencing the education system.

The system of state standards of higher library education of Russia Since 2003 a new system of state standards of higher library education in Russia presented in the following table has come into action:

\begin{tabular}{l|l|l}
\hline Name and code of speciality or direction & Name of received qualification & Period of study \\
\hline $\begin{array}{l}\text { Direction } 531000 \text { "Library- } \\
\text { information resources" }\end{array}$ & $\begin{array}{l}\text { "Bachelor of library } \\
\text { information resources" }\end{array}$ & 4 years \\
\hline $\begin{array}{l}\text { Speciality 052700 "Library- } \\
\text { information activity" }\end{array}$ & $\begin{array}{l}\text { "Librarian-bibliographer, } \\
\text { teacher"; } \\
\text { "Manager of information } \\
\text { resources"; } \\
\text { "Technologist of automated } \\
\text { information resources"; } \\
\text { "Referent-analyst of } \\
\text { information resources" }\end{array}$ & 5 years \\
\hline $\begin{array}{l}\text { Direction 531000 "Library-" } \\
\text { information resources" }\end{array}$ & $\begin{array}{l}\text { Master of library-years } \\
\text { information resources" }\end{array}$ & 6 years \\
\hline
\end{tabular}

What was the new in this system? Distinctive features of a new system of library education standards are the following:

- according to Bologna process in Russia there has been done a transition to multistage library education on the base of introduction of bachelorship and mastership;

- all the universities of culture and arts which have been training librarians bibliographers of higher qualification in speciality "Librarianship and bibliography" turned to a new speciality "Library and information activity";

- introduction of standards' system reflects radical changes connected with social-economical changes in Russia: development of marketing relations, democrating freedom and privacy in a choice of education, setting free of educational institution from ideological dogmas, administrative guardianship and over-reglamentation. The advantage of actual education standards is the possibility to regulate the quality of education, to provide a unified educational space in Russia, to develop multy-level library education; 
- while developing the standards there was used a new strategy - the strategy of collective work. It embodied a temporary creative group consisting of experienced teachers of Moscow, Saint-Petersburg and Kemerovo State Universities of Culture and Arts who were the developers of education standards;

- for the first time there was a close interaction of developers of the education standards with professional library community - Russian Library Association.

\section{In what way there was an interaction among the Universities - developers of standards of higher library education with RLA}

It included the work in the following direction:

- publication the project of a new standard in the newsletter of RLA and on Web-site of RLA, publication of articles devoted to the problems of standardization of library education in professional editions for wide information of library community about new developing standards;

- holding scientific - practical seminars, conferences, round-tables together with RLA that provided a dialogue of teachers and librarians on different levels: regional, Russian and international;

- discussion the standards' project at the section of library profession, staff and long-life education at the annual conferences of RLA (Tver, 2000, Saratov, 2001, Yaroslavl, 2002, Pskov, 2003).

To the analysis and evaluation of this work members of RLA, practical-librarians including the heads of libraries were invited. Everything was done to put away the negative situation which took place before when the standards regulated training the library staff developed without clearly expressed orientation to the needs of library experience and demands of employers and without any attention to the position of national professional association. As the result there was a large scale professional discussion of standards. The leading library-information specialists were invited as the experts that led to the quality rise of developed standards. In the course of mutual work it was admitted that creation of national education library standards' system would serve the base for their integration with analogical education systems of the developed overseas countries. Besides, development of education standards allows creating the national system of evaluation on the professional education quality on the principles of succession and integrity of library education which serves the foundation in developing principles and methods of educational testing, formation of demands' system to the level of librarians' training at every step of education. 


\section{The problems which must be solved at the national level}

Mutual work cleared up the demand in perfection of the interaction's mechanism of higher educational institutions, libraries and Russian Library Association. The solution of this problem supposes its stratification:

- the level of higher educational institution. At this level there is a need of development scientifically based demands of the society in informationlibrary specialists; development of scientific foundation of education programs' contents; development of educational-instructional materials for libraryinformation staff;

- the level of Russian Library Association. On the part of RLA there is a need to make up the consolidated opinion, generalization and expression requirements of libraries to the qualification and quality of library-information specialists of different steps of professional education; discussion and control of standards, evaluation of text-books created in the Universities at the sessions of RLA and in "Proceedings of RLA";

- the level of libraries. The leading specialists of libraries should elaborate and formulate the requirements to qualification and quality of library-information specialists; they also should be the experts in evaluation of education standards and textbooks written in higher educational institutions.

\section{The problems that should be discussed at the international level}

To conclude with it should be stated that standardization of a modern system of education is the all over the world tendency and education standards are the most important tool of evaluation library specialists' training called to pay deep influence for people readiness to live in information society and knowledge society. According to this point of view generalization of Russian experience of interaction of higher educational institutions and professional Library Association allows to come to some conclusions which, to my mind, not only reflect national specification but may be the object of international library community. They are the following:

1. Development and perfection of education standards in library education must be based on the principles of a system approach and integrity. Optimization of existing library education standards must be built on realization of long life education "education during the whole life".

2. Correction of existing ones and development of a new version of education standards requires carrying out complex scientific research work which foresees the mutual forces both higher educational institutions and members of professional associations. Development of library education standards is a specific task of library science within the frame of which there is its selfreflection. So to solve this serious problem it should be done: 
- to identify the goal of library education under conditions of information society and knowledge society;

- to define the criteria of contents of professional library education;

- to define more exactly the criteria of a graduate readiness to professional activity.

This research should provide scientifically based decisions about criteria of differentiation of education contents at various steps of education system (bachelor-specialist-master); to formulate more exactly the requirements to professional competency of graduates who got professional training of different levels, to provide integrity and unity of standards' system for library education.

3. Optimization of standards' system which allows controlling library education's quality should be done under conditions of wide participation of library professional associations in discussion of the quality of education standards in professional papers.

4. The formation of library education standards' system presupposes collegiality, united forces of scientists, university teachers and members of library community, because the standard is based on the agreement of sides as it states a single and optimal norm for majority. The standard is good only when it is well based. The work of education standards' development should be done on the long-term base with compulsory expertise and standards' evaluation for their perfection.

And at last it should be noted that if we take the metaphor offered by IFLA and believe that "Libraries are the heart of information society" then interaction of higher educational institutions and professional library association looks like communication vessels which are the sources of quality rise in training of librarians of XXI century, the century of information and knowledge.

\section{References:}

1. Abdul Waheed Khan. Towards knowledge societies //A World of SCIENCE, Vol. 1, No. 4, July-September 2003

\section{Abstract:}

The main preconditions of library education's renovation are information society establishing, global informatization, rapid development of ICT, realization of information resources as strategical resource of the society, the change of educational paradigm from "education to the rest of life" to "education during the rest of life", strengthening of library role as the most important social institution providing access to knowledge and information. 
The content renovation of library education, training quality rise of library staff is the subject of interest for both higher educational institutions providing highly qualified library specialists' training and professional library community. The result of this work depends on a productive dialogue between the educational institutions and organizations expressing the requirements of professional community to the level of graduates' training. The most important corporate organization of professional community of librarians is library association. The main problem lies in the development of working mechanism of coordination $f$ educational institutions and library associations. It gets a special acuteness under conditions of development and introduction of state educational standards.

During the last decade in Russia the activity of standardization of education including a library one got development. Standardization is deeply connected with renovation of the content of education. Thus, instead of the speciality "Librarianship and bibliography" traditionally taught by the Institutes of Culture and Arts in Russia since 2003 they started training staff in a new speciality "Libraryinformation activity". The standard provides training graduates in such qualifications as "Librarian-bibliographer, teacher", "Manager of information resources", "Technologist of automated information resources" within above-mentioned speciality.

For the first time there was close coordination between developers of educational standards and professional library community - Russian Library Association (RLA) which provided a possibility of a large-scale professional discussion of standards and attraction leading specialists of library-information activity as experts.

However mutual activity demanded the perfection of coordination mechanism of educational institutions, libraries and RLA. The solution of the problem of advanced quality of library staff training requires its stratification:

- Level of educational institutions: development of scientific base of the content of curricula; creation of text-books and educational instruction materials for library-information staff's training;

- Level of RLA: generalization and expressing libraries' requirements to qualification level and quality of library-information staff's training; organization of discussion and examination of standards, instruction books and text-books in the sphere of library education at the RLA sessions and in RLA Newsletter;

- Level of libraries: development and introduction requirements to qualification and quality of information-library specialists' training; participation in examination of educational standards, text and instructional books.

In my opinion, the problem of coordination of educational institutions and professional library associations are not of national but of international character. 